\title{
Fishing Livelihoods and Wellbeing
}

\begin{abstract}
The final chapter of this book discusses the implications of a relational approach to fishing livelihoods for governance for improved social and ecological outcomes. The chapter reviews some of the ways in which academics, activists and policymakers can use approaches that emphasise the relational context of fishing livelihoods, and specifies the concept of wellbeing as one that can usefully and practically build bridges between fisheries stakeholders with diverse interests. The chapter then examines two assessments of fisheries on community wellbeing: the social and economic impacts of fisheries in Australia, and the effects of governance on wellbeing of fishing communities in Indonesia and Solomon Islands.
\end{abstract}

Keywords Fisheries governance • Wellbeing • Relationality

Fishing livelihoods, especially in the Asia-Pacific, remain hugely significant. They produce healthy and nutritious food (Hicks et al., 2019), generate economic opportunities for many millions, play a particularly important role for vulnerable and marginalised groups (Mills et al., 2011) and contribute to the maintenance of traditions and cultures (Allison et al., 2020). Yet, the environmental crises progressively enveloping the globe are particularly acute in the marine systems on which fishing https://doi.org/10.1007/978-3-030-79591-7_5 
livelihoods depend. Climate change, pollution and overfishing are among the many drivers of change to these marine systems that threaten their capacity to sustainably generate marine resources. At the same time, economic, political and social drivers of change are reshaping the structures of social life that dictate how fishing livelihoods operate. While fishing livelihoods have evolved and adapted to many changes over the years, the accelerating scale and pace of change present significant challenges to the very viability of fishing livelihoods in some places. The Asia-Pacific, home to the largest number of fishers and the most diverse marine ecosystems on the planet, is a crucial locus of these developments (Fig. 5.1).

In much fisheries governance literature, fishers are represented as individuals whose sole objective is to maximise the number of fish that they catch, with subsequent environmental effects. From this perspective, governance is a balancing act that seeks to maximise the acquisition of financial wealth while minimising environmental harms. In contrast, this short book has tried to highlight some of the relationships that drive the perspectives and actions of those working in fisheries value chains. Fishing does not occur in isolation, but takes place in relation to a wider environment of other activities, actors and ideas. We have highlighted three relationships that we argue are particularly important to fishing livelihoods: historical patterns of economic and political change, social identities and relations, and institutional structures. Each, in its own way, is an important part of the nature and character of particular fishing livelihoods and, thus, contributes to the diverse social and ecological outcomes associated with fishing.

While these relationships are usually studied from different conceptual perspectives, or in relative isolation from each other, they are largely complementary (Hornborg et al., 2013). In the Philippines, for example, the cases in this book showed how contemporary class structures in fishing livelihoods derive from historical patterns of political and economic change, intertwine with cultural values relating to inequality and influence the differentiated outcomes of governance interventions. Some of the key concepts of political ecology introduced in Chap. 1 are useful reminders of the ways in which fishing livelihoods are constituted by these multiple, shifting relationships. Attention to wider scales of analysis and to historical pathways of change, for example, shows how the conditions of fishing livelihoods are generated by broader processes that go well beyond the day-to-day activities of harvesting fish and other local activities. And recognition that politicised environments (Bryant \& Bailey, 1997) are the 


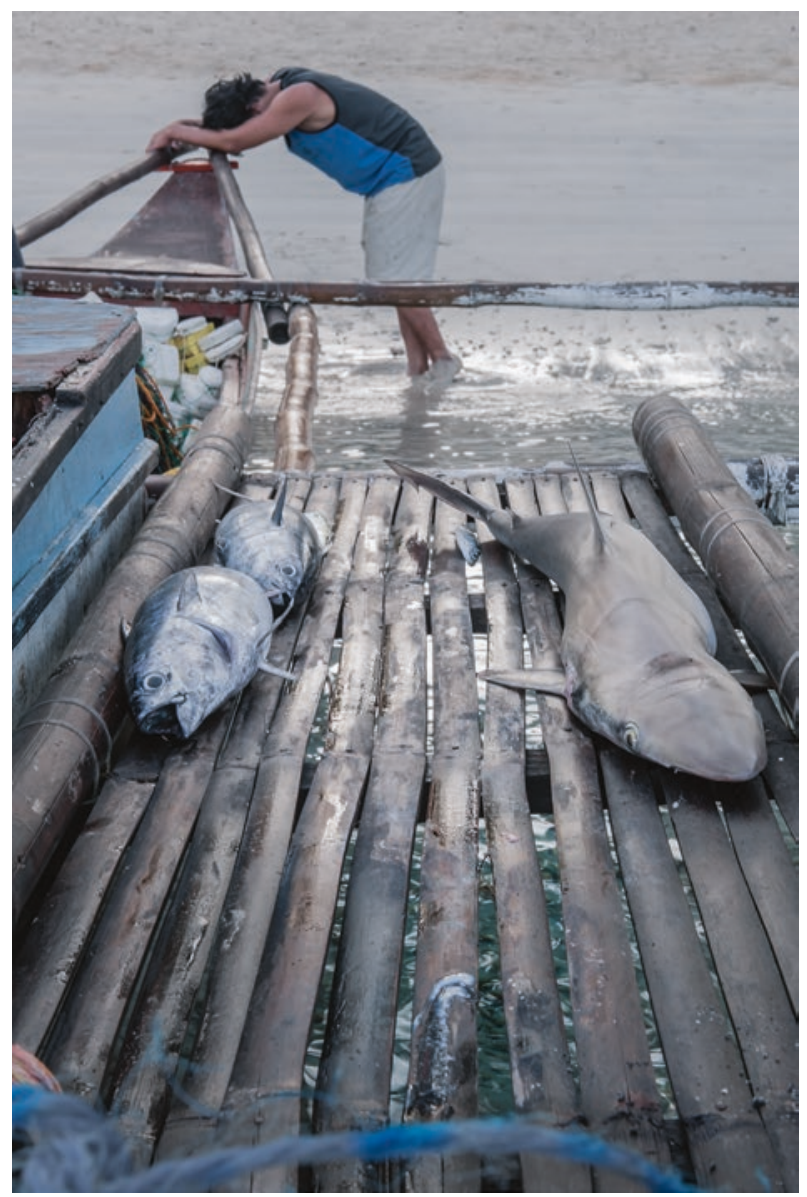

Fig. 5.1 A fisher returns from a night at sea in North-East Palawan, Philippines. (Photo credit: Katherine Jack)

norm rather than unusual shows how the social relationships constituting fishing livelihoods, and the governance interventions that seek to manage them, are experienced in unequal and distinctive ways by different individuals and groups.

This concluding chapter sets out the pragmatic implications of this relational perspective in the applied sphere. When the focus shifts from the act 
of fishing itself to the wider sets of relationships in which fishing livelihoods are embedded, opportunities for action emerge in new spaces. Understanding fishing in relation to past and present patterns of economic development, in relation to social inequities, and in relation to the social effects of governance regimes, increasingly informs the work of many academics, activists and even those in government. The fundamental role of markets and trade in fishing has led to the formation of new coalitions seeking to harness the power of these markets for improved, more ecologically sustainable growth through the sustainable seafood movement. On the other side of the ideological spectrum, focusing on unequal patterns of economic growth has led to trenchant critiques of the current economic system and its incarnations in 'blue growth' policies (Mallin \& Barbesgaard, 2020) or industrial fishing (Longo et al., 2015), as well as advocacy of alternatives such as degrowth (Hadjimichael, 2018) and blue justice (Isaacs, 2019). Similarly, environmentalists draw attention to the enormous costs of our economic system for the environment, in particular for carbon emissions and climate change (Hughes et al., 2017).

At a more micro scale, understanding how patterns of power reproduce themselves in day-to-day interactions and relationships informs much academic and applied social science work on fishing livelihoods. For example, much work on value chains seeks to improve the capacity of fishers to 'upgrade' their position in the value chain, through the development of new skills or access to new technologies (Cole et al., 2018; Purcell, 2014), or access to better market information (Purcell et al., 2017). Increasingly, governments, donors and environmental NGOs are working to address the position of marginalised groups such as women (Barclay et al., 2019; Kleiber et al., 2019; Lawless et al., 2017; USAID Oceans and Fisheries Partnership, 2019). The issue of working conditions and rights among fishers, particularly those working on industrial fishing vessels, is now prompting governments and corporations to address these issues (Kittinger et al., 2017).

Attention to the relationships between fishing livelihoods and institutions, particularly institutional inequities, also informs much social science work and activism, and has driven change in dominant models of fisheries governance. Attention to the role and rights of communities was one of the major drivers behind co-management, for example, which has been adopted in various ways in many parts of the Asia-Pacific (Ratner et al., 2012). Similarly, in many contexts state models of fisheries governance must work with customary marine tenure and access rules (Rohe et al., 
2019). A focus on the rights of fishers has led to the development of the Voluntary Guidelines for Securing Sustainable Small-Scale Fisheries, and a thriving coalition of groups advocating for greater visibility and support for small-scale fishers (Jentoft, 2019).

In the remainder of this chapter, we return to the theme of wellbeing introduced in Chap. 1 and discuss some of the practical ways in which this concept can be operationalised and used to contribute towards better ecological and social outcomes. The concept of wellbeing is no panacea (Young et al., 2018) or blueprint (Ratner \& Allison, 2012); it is not a new model for governance that can be expected to work effectively in the same way in every context. However, one of the strengths of the wellbeing concept is its ability to bridge between different stakeholders involved in fisheries governance and scholarship.

For many fisheries policymakers and managers, the findings of social scientists (e.g., detailed ethnographic investigations) are often 'interesting' but ultimately difficult to operationalise, 'unscientific', or 'a bit touchy feely', as one prominent fisheries scientist advised author Fabinyi at a technical workshop. Conversely, for many social scientists, such as anthropologists fascinated by the complexities and contradictions in human societies, the tendency in many economic models and in much fisheries policy to discuss fishers in terms of numbers (catch, value, volume, number of fishers, etc.) is a gross simplification of underlying key social processes and structures. So often, the debates between economists, policymakers and social scientists become 'bogged down' in sterile and unproductive arguments because of these fundamentally different assumptions about knowledge. Wellbeing, we argue, is a concept that can help to incorporate some of the complex issues addressed by social scientists in a way that can be recognised, understood and acted on by fisheries policymakers. It is useful for exploring the interrelated environmental, political and economic aspects of fisheries.

One reason the wellbeing approach is useful for bringing together disparate knowledge systems is that it addresses a shared high-level goal: the wellbeing of human communities (Stiglitz et al., 2018). Using fisheries resources for the benefit of the people is usually the overarching aim stated in fisheries legislation, so it is clearly in the purview of fisheries managers. The conceptualisation of wellbeing most often used in fisheries draws from development studies, adapted from Amartya Sen's capabilities approach (Sen et al., 1987). It is described as 'a state of being with others, which arises where human needs are met, where one can act meaningfully 
to pursue one's goals, and where one can enjoy a satisfactory quality of life' (McGregor 2008, cited in Coulthard et al., 2011: 79).

Another reason the wellbeing approach enables participation from across disciplines is that it is a framework, rather than a method itself. Various methods are used, often mixed to gain a comprehensive picture (McGregor et al., 2015), such as qualitative interviews, social psychological tools (Britton \& Coulthard, 2013; Coulthard et al., 2014), semiquantitative questionnaires, economic analysis (Voyer et al., 2017) and ecosystem services methods (Chaigneau et al., 2019; Masterson et al., 2019). Thus, people from different disciplinary perspectives are usually able to see some kind of method they recognise as rigorous and appropriate in wellbeing studies. The holistic emphasis in wellbeing studies means that different domains of life are examined-from straightforward economic benefits to political relationships.

Wellbeing has been used to assess the condition of fishing communities (Britton \& Coulthard, 2013; Coulthard et al., 2011, 2014; Smith \& Clay, 2010 ) as well as the human dimensions in ecosystem-based resource management (e.g., Breslow et al., 2016). These uses of the wellbeing approach involve asking the question, 'what is the wellbeing of community $x$ ?' For example, the University of Canberra runs annual wellbeing surveys of rural areas in Australia, using established psychological questionnaires for individual and community wellbeing, enabling comparison across regions, across demographic groups in populations, and over time. ${ }^{1}$ It has been used to compare the wellbeing of fishers against the rest of the population (Barclay et al., 2020).

Wellbeing has also been used to assess effects on communities. These uses involve asking the question, 'what are the effects of $y$ on the wellbeing of community $x$ ?' (e.g., measuring the wellbeing benefits people gain from coastal ecosystem services) (Chaigneau et al., 2019; Masterson et al., 2019; McMichael et al., 2005). Thus, wellbeing is a suitable framework for social impact assessments. Other conceptual frameworks used for understanding social impacts in fishing communities include resilience and vulnerability. There are some examples of ongoing monitoring of social and economic conditions in relation to marine ecosystems; although, these do not use a wellbeing framework (i.e., the Social and Economic

\footnotetext{
${ }^{1}$ Information about the Australian Regional Wellbeing Survey is available at https://www. canberra.edu.au/research/institutes/health-research-institute/regional-wellbeing-survey/ survey-results
} 
Long-Term Monitoring Program for the Great Barrier Reef in Australia, ${ }^{2}$ and the collection of data on social indicators for coastal and ocean ecosystems across the US) (Ramenzoni \& Yoskowitz, 2017). A study in Bangladesh showed the effects of different types of aquaculture through comparing the wellbeing of a village engaged in rearing tiger shrimp with another village rearing freshwater prawn (Belton, 2016). The wellbeing approach has also been used to specifically assess the effects of fisheries on community wellbeing. The following cases examine two such assessments.

\section{Social ANd Economic EfFects of Fisheries in Australia}

There have been two large evaluations of the effects of fisheries on the wellbeing of communities in Australia, for the states of New South Wales (Voyer et al., 2016, 2017) and Victoria (Abernethy et al., 2020). The impetus for these studies was the lack of public and government support for fisheries in Australia noted in Chap. 4. Fishing industry bodies felt that robust evidence about the positive effects fisheries have on communities where fishing occurs would help their advocacy efforts to improve public perceptions about fisheries, and ensure continued access to fisheries resources.

The studies involved a two-step process. First, the areas of community life or domains of wellbeing to which fisheries can contribute were identified, through the literature on wellbeing and qualitative interviews with fishers and others in fishing communities. Second, the specific contributions fisheries can make to those areas of community life were identified (see Table 5.1). These contributions were investigated through a mix of qualitative interviews, document review, a semi-quantitative phone survey, and economics analysis, including contributions to regional economies using input-output methods.

Since wellbeing is multidimensional (McGregor et al., 2015; Stiglitz et al., 2018), fisheries contributions were considered as having material, subjective and relational dimensions. Material contributions are easy to understand-they include food, income and assets, access to services, and environmental quality. Fisheries contributions to subjective wellbeing are effects on people's perceptions of their quality of life and the values and

\footnotetext{
${ }^{2}$ The Social and Economic Long-Term Monitoring Program data for the Great Barrier Reef are available at https://data.csiro.au/dap/landingpage?pid=csiro:38797
} 
Table 5.1 Fisheries-relevant domains of community wellbeing, and fisheries contributions to those domains

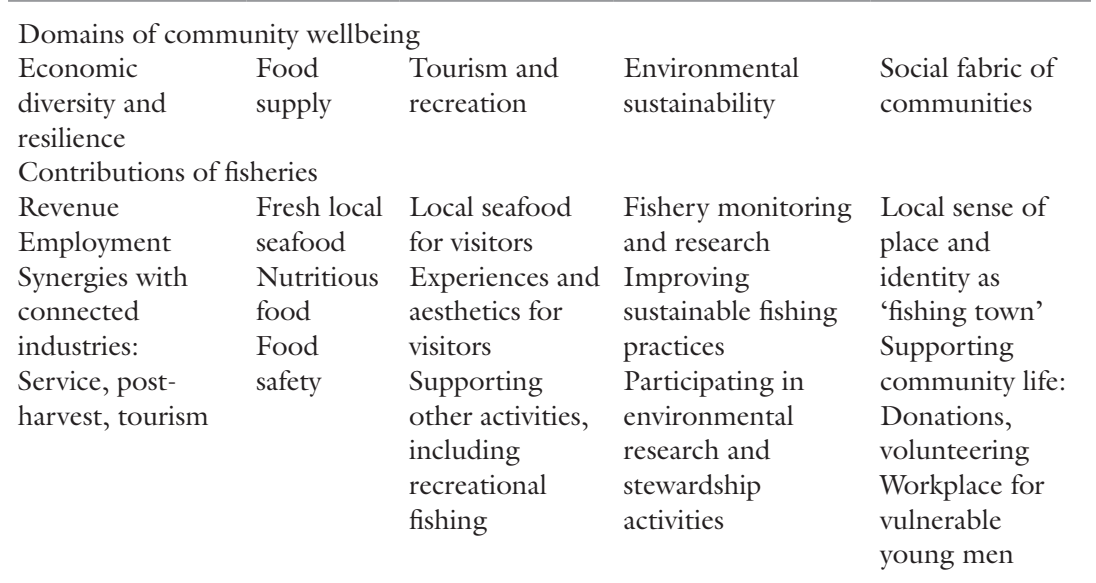

Source: Abernethy et al. (2020)

beliefs that shape their levels of satisfaction, such as whether they feel it is a good thing to be eating locally produced seafood or believe that fishers are operating in ways that sustain the marine environment. Relational aspects include whether fishers contribute to the development and maintenance of relationships that enable communities to achieve wellbeing, such as through donating to or volunteering in community activities like sports or festivals, or through business and political connections that may benefit communities.

The picture of fisheries that emerges from a wellbeing analysis really illuminates livelihoods. Before these studies were conducted the only existing data were statewide fisheries' gross value of production (i.e., volume of catch multiplied by beach price), and rough job numbers from census data. The wellbeing economic analysis expanded the view to consider businesses supplying services and gear to fishers, as well as the flowon to businesses in seafood processing and wholesaling. The input-output method estimated the level of economic activity fishing generated in regions, down to local government areas, as well as the proportion of this going to household incomes, and the numbers of jobs in fishing, processing and wholesaling. 
This kind of material information is certainly useful for making claims about the importance of fishing to communities, but the multidimensional mixed-methods approach greatly deepened the understanding generated. For example, the qualitative interviews and phone survey revealed the close connections between fisheries and tourism-another key economic activity in many fishing communities. It is not just that the two sectors support each other, but tourism in many locations is seasonal whereas fishing is year round, so having fishing as well as tourism is important for local economies. The interviews also revealed that it is not only the numbers of jobs that are important but also the types. Entry-level employment in fisheries is valued in rural areas, because without entry-level work young people have to leave to seek employment elsewhere. Moreover, fisheries work does not require high levels of formal schooling, so it has been a good opportunity for young men who struggled at school or who were 'getting into trouble' and likely heading towards a life of crime and/or welfare dependency.

Finally, looking for contributions to subjective aspects of fishing reveals another element about livelihoods. Some fishers are deeply attached to fishing as a way of life. When they are forced to leave fishing work they become depressed. For these people working on the water, feeling the majesty of the elements and other living creatures, and the satisfaction from surviving and thriving in this work, is about much more than the income they make: it is part of their psychological wellbeing. There is an added layer of importance for Indigenous peoples. Australian Aboriginal and Torres Strait Islanders gain significant and measurable benefits from working on Country, caring for their environment, gaining sustenance from it, sharing food from it and developing and sharing knowledge about it. Therefore, having the opportunity to pursue a livelihood in fishing is about far more than cash income or dietary nutrients-although those material elements are also undeniably important. A wellbeing approach examining relational and subjective, as well as material dimensions, gives a holistic picture of the effects fishing has on communities.

\section{Effects of Governance on Wellbeing of Fishing Communities in INDONEsia AND SOlOMON IsLANDS}

A slightly different tack was taken in looking at the wellbeing contributions of tuna fisheries to coastal communities in Indonesia and Solomon Islands (McClean et al., 2019). The impetus for this study was a deficit in 
existing fisheries governance analyses. Around the world the overarching objective for fisheries management enshrined in fisheries legislation is almost always to benefit society, but fisheries management science virtually never considers the social or economic benefits from fisheries in a systematic way: fisheries management science is usually about fish stocks. Sometimes there is an economic element such as 'maximum economic yield' or bio-economic modelling-both of which often focus on fishing business profitability - or more basic information about contribution to national GDP, gross value of production or total numbers of jobs. Each of these approaches is 'broad brush' and does not give the fine-grained, multidimensional understanding of economic effects achieved in the Australian studies using a wellbeing approach. Non-economic social benefits are rarely examined in fisheries science at all.

Therefore, the project asked the question, 'what are the effects of different types of fisheries governance on the wellbeing generated through tuna fisheries in coastal communities?' The stages involved in answering this question included identifying ( 1 ) the fisheries-relevant domains of wellbeing in Indonesia and Solomon Islands contexts; (2) the contributions tuna fisheries make to those domains; (3) the types of governance affecting those contributions; and (4) the effects those forms of governance have on wellbeing contributions from tuna fisheries. 'Governance' here is understood broadly to include all social, economic and political institutions shaping fisheries, as well as specific fisheries regulations, as per insights from governance studies (Kooiman et al., 2005). For example, private sector interventions such as certification for MSC and fair trade and differential access to markets are part of governance.

The scope of this project precluded economic analysis or large-scale questionnaire data collection. It relied on qualitative interviews (134 across both countries) and review of documents, and existing social, economic and fisheries data. It would be useful to also have quantitative social and economic data and analysis. At the time of writing the researchers were pursuing this in subsequent research.

However, even without quantitative data or analysis the qualitative wellbeing analysis produced an approach for assessing governance that can help fisheries managers and stakeholders start to grasp the implications of different governance interventions for the wellbeing of target communities. Table 5.2 outlines a framework that can be used to conduct a 'first pass' assessment that can help illuminate likely social and economic effects of a governance intervention. This framework can also highlight 
Table 5.2 Framework for assessing fisheries governance in terms of community wellbeing

The potential governance intervention The fishery affected

Status quo wellbeing impacts

Potential benefits to coastal communities from the intervention Who benefits from the governance intervention?

Potential lost benefits to coastal communities Who in the value chain bears the loss/ is exposed to risk from the intervention Factors influencing effectiveness and the ability to mitigate risks/vulnerabilities
List the intended changes in a fishery, or set of fisheries management options

Include relevant information on gear/vessel type, target species, geographical focus, destination market or any other characteristics of the fishery that are relevant in determining the scope of the intervention.

List the actors, communities or stakeholders who currently receive benefits, or are exposed to risk or insecurity, from the fishery. Wellbeing impacts may be in the domains of economy, food and nutritional security, workplace health and safety, healthy environmental systems and poverty alleviation. Close consideration should be paid to the distribution of those benefits according to socio-economic status, migrant status and gender. Note intended or anticipated wellbeing benefits that would arise from the initiative, as well as whether these are likely to be realised in the short, medium or long term.

List the actors, communities or stakeholders who would receive the benefit. Close consideration should be paid to socio-economic status, participation of migrant communities or migrant labour, and gender.

Note wellbeing benefits that may be lost as a result of the intervention (such as livelihoods if catches are restricted), with likely time frame (short, medium or long term).

List the actors, communities or stakeholders who might lose benefits, or be exposed to risks. Close consideration should be paid to socio-economic status, migrant status and gender.

List any factors likely to influence the effectiveness of an initiative, or mitigate the risks of an initiative (e.g., the presence of alternative livelihoods and food sources, or the presence of effective monitoring or management systems). This allows for realistic assessment of the feasibility of an initiative in the context of a specific fishery and management system.

knowledge gaps, both to orient future research efforts to provide better data and quantitative analysis, and improve the evidence base. For example, this includes household incomes coming from tuna industries, numbers and types of jobs, which social groups have which types of jobs, and contributions to regional economies, among other factors. Ideally, there 
should be ongoing monitoring of social and economic aspects of fisheries, so that social and economic factors can become part of routine fisheries science, and so that data are available for when social and economic impact assessments are needed.

The main areas of wellbeing benefit that emerged in the project were economy and livelihoods, food and nutritional security, and environmentally sustainable fisheries. Tuna industries give rise to formal and informal employment and large and small business opportunities in fishing, trading and processing, as well as in supplying inputs and services for fishing and processing. Indonesian Government statistics on fisheries employment do not break down the numbers for tuna, but it is a prominent part of the economy in many coastal areas. For example, in the tuna port of Bitung in North Sulawesi, in 2018 there were over 8000 people employed in fishing and processing, with many more working in supply chains for markets in the regions surrounding Bitung (McClean et al., 2019). In Solomon Islands the tuna fishing and processing sector based in Noro in Western Province has long been the largest private sector employer in the country. It formally employed around 2400 people in 2018, and has long been a large employer of women, who work on the processing lines (McClean et al., 2019). In addition, there are hundreds of people doing small-scale tuna fishing and selling tuna in urban markets, both catch from the smallscale fisheries and rejects from the industrial fisheries. The cannery in Noro, which has a canteen for its workers, buys fresh vegetables from around 500 farmers in the surrounding area (McClean et al., 2019).

The subjective aspects of livelihoods were given less weight by interviewees than in the Australian studies, possibly due to the different situations of Indonesia and Solomon Islands as developing countries. Interviewees were mainly concerned with the material dimensions of livelihoods. Nevertheless, the broad view of the wellbeing approach-paying attention to relational and subjective dimensions, as well as material and the use of qualitative methods - helped develop a holistic picture of livelihoods. The two key findings about tuna livelihoods that emerged from this study were the workplace health and safety and income insecurity risks that are involved in some livelihoods, and the distribution of different livelihood opportunities across groups within society, particularly in relation to socio-economic status, ethnicity and/or migrant status, and gender.

The quality of many tuna livelihoods in Indonesia and Solomon Islands is greatly affected by security of income as well as workplace health and safety. Indonesian fishing crews are largely informally recruited: they have 
no contract, insecure catch-share models of remuneration and little health insurance coverage. There are injuries working with heavy equipment at sea, and crews of small-scale fishing vessels are sometimes lost. Indonesian tuna fishing crews are often among those found to be suffering human rights abuses through poor labour conditions, and even forced labour. In contrast, formal sector workers in processing factories are contracted, have minimum wage conditions, and are usually covered by various forms of social and health insurance. In Solomon Islands working conditions on vessels in the domestic fleet are some of the best in the region. Formal tuna processing work is similar in conditions and protections to Indonesia. Informal fishing, processing and trading work are likewise more insecure, without insurance protection, and small-scale fishing is similarly dangerous, with crew occasionally lost at sea.

The incomes for entry-level work in both Indonesia and Solomon Islands, in both formal and informal sectors, are very low, often around the poverty line-although this is not always the case. For example, Solomon Islands women cooking and selling tuna informally in markets make a great deal more than cannery workers. Financial literacy also makes a big difference in Solomon Islands, with some small-scale fishers and cannery workers who have had financial literacy training able to make their incomes go a lot further than others in terms of housing, covering weekly household expenses and so on. In Indonesia, some petty traders have worked their way up into running lucrative businesses (McClean et al., 2019).

Thus, entry-level tuna industry work in Indonesia is mainly filled by low socio-economic status groups. Often, this corresponds with migrant status, which can mean internal migration within Indonesia, such as Butonese fishers operating in Maluku. In Bitung there are many different internal migrants drawn by the availability of tuna work, and there has historically been a strong presence of Filipino fishers in Bitung. The Butonese people fishing in Maluku are marginalised and tuna fishing is one of the only options available to them. In Solomon Islands remuneration in the tuna sector is on par with other sectors, so formal tuna work is sought by people from all groups in society. However, small-scale tuna fishing does align with low socio-economic or migrant status. The reasons for this are complicated and include the fact that people with I-Kiribati heritage have more skills and knowledge in offshore fishing than most Indigenous Solomon Islanders, but according to interviewees also include the marginalised status of people who migrated from Kiribati. More 
research would be needed to observe whether tuna livelihoods act to alleviate poverty, or if the low incomes keep marginalised people in low socioeconomic situations.

Another clear social differentiation in tuna livelihoods is by gender. Tuna fisheries are some of the more male-dominated fisheries, and very few women are engaged in tuna fishing in Solomon Islands or Indonesia. However, women are heavily involved in processing and trading. In formal processing women in both countries make up the majority of workers on tuna 'cleaning' lines, preparing the tuna meat for putting in cans. They work in administration, management and technical roles in processing factories. Women as well as men are also involved in informal trade of tuna and small-scale processing such as smoking or cooking tuna for sale. However, in both countries, men tend to cluster around the larger, highervalue parts of business, with women correspondingly clustered around smaller-scale, lower-value activities and lower-authority positions. Therefore, livelihood opportunities in tuna industries in both countries are shaped by gender as well as ethnicity and socio-economic status.

\section{CONCLUSION}

Fishing livelihoods currently face a series of profound and interrelated economic, environmental and social challenges that negatively affect and threaten their viability. While these challenges are increasingly well understood-from climate change to overfishing, and from new government regulation to increasing competition over marine and inland fisheries resources with other economic sectors-the solutions to these challenges are much harder to encounter. This reflects the reality that fisheries and coastal governance is inherently a 'wicked problem'-one where there are many dynamic factors and stakeholders, where there are no technical solutions and where it is not even clear when the problem is 'solved' (Jentoft \& Chuenpagdee, 2009).

The final chapter of this book discussed how the wellbeing approach can help to shift the dominant focus in fisheries governance and policymaking from economic benefits and environmental effects alone, to one that considers the wider relations by which fishing livelihoods are shaped. A wellbeing approach as described in this chapter can reveal the different dimensions of wellbeing to which fishing livelihoods contribute, and how fisheries managers and stakeholders can assess the consequences of specific governance interventions for the wellbeing of fishing communities. 
Fishing livelihoods will continue to change in relation to the wider world of which they are part. Understanding and incorporating these relationships into the knowledge informing decision-making is one way that the wider fisheries policymaking and management community can ultimately contribute to the improvement and sustainability of fishing livelihoods.

\section{REFERENCES}

Abernethy, K., Barclay, K., McIlgorm, A., Gilmour, P., McClean, N., \& Davey, J. (2020). Victoria's fisheries and aquaculture: Economic and social contributions. Research project. FRDC 2017-092. Sydney: University of Technology Sydney. Retrieved January 7, 2021, from https://www.uts.edu.au/about/ faculty-arts-and-social-sciences/research/fass-research-projects/socialscience-fisheries/victorias-fisheries-and-aquaculture-economic-andsocial-contributions

Allison, E.H., Kurien, J., Ota, Y., Adhuri, D. S., Bavinck, J.M., CisnerosMontemayor, A., Olukoju, A., et al. (2020). The human relationship with our ocean planet. Washington, DC: World Resources Institute. Retrieved February 9, 2021, from https://www.oceanpanel.org/blue-papers/HumanRelation shipwithOurOceanPlanet

Barclay, K., Leduc, B., Mangubhai, S., \& Donato-Hunt, C. (Eds.). (2019). Pacific bandbook for gender equity and social inclusion in coastal fisheries and aquaculture (1st ed.). Noumea.

Barclay, K., Davila, F., Kim, Y., McClean, N., \& Mcilgorm, A. (2020). Economic analysis and social and economic monitoring following the NSW Commercial Fisheries Business Adjustment Program. Sydney: Institute for Sustainable Futures, University of Technology Sydney. Retrieved January 7, 2021, from https://www.dpi.nsw.gov.au/__data/assets/pdf_file/0007/1256128/ Economic-analysis-and-Social-and-Economic-monitoring-following-theNSW-Commercial-Fisheries-Business-Adjustment-Program.pdf

Belton, B. (2016). Shrimp, prawn and the political economy of social wellbeing in rural Bangladesh. Journal of Rural Studies, 45, 230-242. https://doi. org/10.1016/j.jrurstud.2016.03.014

Breslow, S. J., Sojka, B., Barnea, R., Basurto, X., Carothers, C., Charnley, S., Coulthard, S., et al. (2016). Conceptualizing and operationalizing human wellbeing for ecosystem assessment and management. Environmental Science and Policy, 66, 250-259. https://doi.org/10.1016/j.envsci.2016.06.023

Britton, E., \& Coulthard, S. (2013). Assessing the social wellbeing of Northern Ireland's fishing society using a three-dimensional approach. Marine Policy, 37, 28-36. https://doi.org/10.1016/j.marpol.2012.04.011

Bryant, R. L., \& Bailey, S. (1997). Third world political ecology. Routledge. 
Chaigneau, T., Brown, K., Coulthard, S., Daw, T. M., \& Szaboova, L. (2019). Money, use and experience: Identifying the mechanisms through which ecosystem services contribute to wellbeing in coastal Kenya and Mozambique. Ecosystem Services, 38, 100957. https://doi.org/10.1016/j. ecoser.2019.100957

Cole, S. M. C., McDougall, C., Kaminski, A. M., Kefi, A. S., Chilala, A., \& Chisule, G. (2018). Postharvest fish losses and unequal gender relations: Drivers of the social-ecological trap in the Barotse Floodplain fishery, Zambia. Ecology and Society, 23(2), 18. https://doi.org/10.5751/ES-09950-230218

Coulthard, S., Johnson, D., \& McGregor, J. A. (2011). Poverty, sustainability and human wellbeing: A social wellbeing approach to the global fisheries crisis. Global Environmental Change, 21(2), 453-463. https://doi.org/10.1016/j. gloenvcha.2011.01.003

Coulthard, S., Sandaruwan, L., Paranamana, N., \& Koralgama, D. (2014). Taking a well-being approach to fisheries research: Insights from a Sri Lankan fishing village and relevance for sustainable fisheries. In L. Camfield (Ed.), Methodological challenges and new approaches to research in international development (pp. 76-100). Palgrave Macmillan.

Hadjimichael, M. (2018). A call for a blue degrowth: Unravelling the European Union's fisheries and maritime policies. Marine Policy, 94, 158-164. https:// doi.org/10.1016/j.marpol.2018.05.007

Hicks, C. C., Cohen, P. J., Graham, N. A. J., Nash, K. L., Allison, E. H., D’Lima, C., MacNeil, M. A., et al. (2019). Harnessing global fisheries to tackle micronutrient deficiencies. Nature, 574(7776), 95-98. https://doi.org/10.1038/ s41586-019-1592-6

Hornborg, A., Clark, B., \& Hermele, K. (2013). Introduction: Ecology and power. In A. Hornborg, B. Clark, \& K. Hermele (Eds.), Ecology and power: Struggles over land and material resources in the past, present and future (Vol. 18). Routledge.

Hughes, T. P., Barnes, M. L., Bellwood, D. R., Cinner, J. E., Cumming, G. S., Jackson, J. B., Palumbi, S. R., et al. (2017). Coral reefs in the Anthropocene. Nature, 546(7656), 82-90. https://doi.org/10.1038/nature22901

Isaacs, M. (2019). Is the blue justice concept a human rights agenda? University of the Western Cape, Institute for Poverty, Land and Agrarian Studies Policy Brief No. 54. Retrieved February 9, 2021, from https://www.africaportal.org/documents/20620/POLICY_BRIEF_54-BLUE_JUSTICE.pdf

Jentoft, S. (2019). Life above water: Essays on human experiences of small-scale fisheries. TBTI Global Book Series 1. TBTI Global.

Jentoft, S., \& Chuenpagdee, R. (2009). Fisheries and coastal governance as a wicked problem. Marine Policy, 33(4), 553-560. https://doi.org/10.1016/j. marpol.2008.12.002 
Kittinger, J. N., Teh, L. C. L., Allison, E. H., Bennett, N. J., Crowder, L. B., Finkbeiner, E. M., Young, J., et al. (2017). Committing to socially responsible seafood. Science, 356(6341), 912-913. https://doi.org/10.1126/science.aam9969

Kleiber, D., Cohen, P., Gomese, C., \& McDougall, C. (2019). Gender-integrated research for development in Pacific coastal fisheries. Program Brief: FISH-2019-02. Penang: CGIAR Research Program on Fish Agri-Food Systems.

Kooiman, J., Bavinck, M., Jentoft, S., \& Pullin, R. (Eds.). (2005). Fish for life: Interactive governance for fisheries. Amsterdam University Press.

Lawless, S., Doyle, K., Cohen, P., Eriksson, H., Schwarz, A.M., Teioli, H., Vavekaramui, A., et al. (2017). Considering gender: Practical guidance for rural development initiatives in Solomon Islands. Program Brief 2017-22. Penang: WorldFish.

Longo, S. B., Clausen, R., \& Clark, B. (2015). The tragedy of the commodity: Oceans, fisheries, and aquaculture. Rutgers University Press.

Mallin, F., \& Barbesgaard, M. (2020). Awash with contradiction: Capital, ocean space and the logics of the blue economy paradigm. Geoforum, 113, 121-132. https://doi.org/10.1016/j.geoforum.2020.04.021

Masterson, V. A., Vetter, S., Chaigneau, T., Daw, T. M., Selomane, O., Hamann, M., Wong, G. Y., et al. (2019). Revisiting the relationships between human well-being and ecosystems in dynamic social-ecological systems: Implications for stewardship and development. Global Sustainability, 2(e8), 1-14. https:// doi.org/10.1017/S205947981900005X

McClean, N., Barclay, K., Fabinyi, M., Adhuri, D.S., Sulu, R.J., Indrabudi, T. (2019). Assessing tuna fisheries governance for community wellbeing: Case studies from Indonesia and Solomon Islands. Sydney: University of Technology Sydney. Retrieved January 7, 2021, from https://www.uts.edu.au/about/ faculty-arts-and-social-sciences/research/fass-research-projects / assessing-governance-tuna

McGregor, A., Coulthard, S., \& Camfield, L. A. (2015). Measuring what matters: The role of well-being methods in development policy and practice. Development Progress Project Note 04. London: Overseas Development Institute.

McMichael, A., Scholes, R., Hefny, M., Pereira, E., Palm, C., \& Foale, S. (2005). Linking ecosystem services and human well-being. In D. Capistrano, K. C. Samper, M. J. Lee, \& C. Raudsepp-Hearne (Eds.), Ecosystems and human well-being: Multi-scale assessments (pp. 43-60). Millennium Ecosystem Assessment Series 4. Washington, DC: Island Press.

Mills, D. J., Westlund, L., de Graaf, G., Kura, Y., Willman, R., \& Kelleher, K. (2011). Under-reported and undervalued: Small-scale fisheries in the developing world. In R. S. Pomeroy \& N. L. Andrew (Eds.), Small-scale fisheries management: Frameworks and approaches for the developing world (pp. 1-15). Cabi. 
Purcell, S.W. (2014). Processing sea cucumbers into bêche-de-mer: A manual for Pacific Island fishers. Noumea: Secretariat of the Pacific community; Lismore: Southern Cross University.

Purcell, S. W., Crona, B. I., Lalavanua, W., \& Eriksson, H. (2017). Distribution of economic returns in small-scale fisheries for international markets: A valuechain analysis. Marine Policy, 86, 9-16. https://doi.org/10.1016/j. marpol.2017.09.001

Ramenzoni, V. C., \& Yoskowitz, D. (2017). Systematic review of recent social indicator efforts in US coastal and ocean ecosystems (2000-2016). Environment and Society: Advances in Research, 8(1), 9-39. https://doi.org/10.3167/ ares.2017.080102

Ratner, B. D., \& Allison, E. H. (2012). Wealth, rights, and resilience: An agenda for governance reform in small-scale fisheries. Development Policy Review, 30(4), 371-398. https://doi.org/10.1111/j.1467-7679.2012.00581.x

Ratner, B. D., Oh, E. J. V., \& Pomeroy, R. S. (2012). Navigating change: Secondgeneration challenges of small-scale fisheries co-management in the Philippines and Vietnam. Journal of Environmental Management, 107, 131-139. https:// doi.org/10.1016/j.jenvman.2012.04.014

Rohe, J. R., Govan, H., Schlüter, A., \& Ferse, S. C. A. (2019). A legal pluralism perspective on coastal fisheries governance in two Pacific Island countries. Marine Policy, 100, 90-97. https://doi.org/10.1016/j.marpol.2018.11.020

Sen, A., Muellbauer, J., \& Hawthorn, G. (1987). The standard ofliving. Cambridge University Press.

Smith, C. L., \& Clay, P. M. (2010). Measuring subjective and objective wellbeing: Analyses from five marine commercial fisheries. Human Organization, 69(2), 158-168. https://doi.org/10.17730/humo.69.2.b83x6t44878u4782

Stiglitz, J. E., Fitoussi, J.-P., \& Durand, M. (2018). Beyond GDP: Measuring what counts for economic and social performance. OECD Publishing. https://doi. org/10.1787/9789264307292-en

USAID Oceans and Fisheries Partnership. (2019). Assessing fisheries in a new era: Extended guidance for rapid appraisals of fisheries management systems. Prepared for the US Agency for International Development by Tetra Tech ARD under Contract No. AID-486-C-15-00001. Retrieved February 9, 2021, from https://www.seafdec-oceanspartnership.org/wp-content/uploads/USAIDOceans_Assessing-Fisheries_RAFMS-Guide_April-2019.pdf

Voyer, M., Barclay, K., Mcllgorm, A., \& Mazur, N. (2016). Social and economic evaluation of NSW coastal professional wild-catch fisheries. Research project. FRDC 2014/301. Sydney: University of Technology Sydney. Retrieved January 7, 2021, from https://www.uts.edu.au/about/faculty-arts-andsocial-sciences/research/fass-research-projects/social-science-fisheries / valuing-coastal-fisheries 
Voyer, M., Barclay, K., McIlgorm, A., \& Mazur, N. (2017). Using a well-being approach to develop a framework for an integrated socio-economic evaluation of professional fishing. Fish and Fisheries, 18(6), 1134-1149. https://doi. org/10.1111/faf.12229

Young, O. R., Webster, D. G., Cox, M. E., Raakjær, J., Blaxekjær, L. Ø., Einarsson, N., Carothers, C., et al. (2018). Moving beyond panaceas in fisheries governance. Proceedings of the National Academy of Sciences, 115(37), 9065-9073. https://doi.org/10.1073/pnas.1716545115

Open Access This chapter is licensed under the terms of the Creative Commons Attribution 4.0 International License (http://creativecommons.org/licenses/ by $/ 4.0 /$ ), which permits use, sharing, adaptation, distribution and reproduction in any medium or format, as long as you give appropriate credit to the original author(s) and the source, provide a link to the Creative Commons licence and indicate if changes were made.

The images or other third party material in this chapter are included in the chapter's Creative Commons licence, unless indicated otherwise in a credit line to the material. If material is not included in the chapter's Creative Commons licence and your intended use is not permitted by statutory regulation or exceeds the permitted use, you will need to obtain permission directly from the copyright holder.

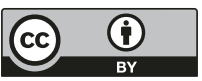

